UCRL-ID-132284

\title{
Receiving, Handling, and Storage of Specimens for Long-Term Corrosion Testing
}

Greg Gdowski

September 11, 1995

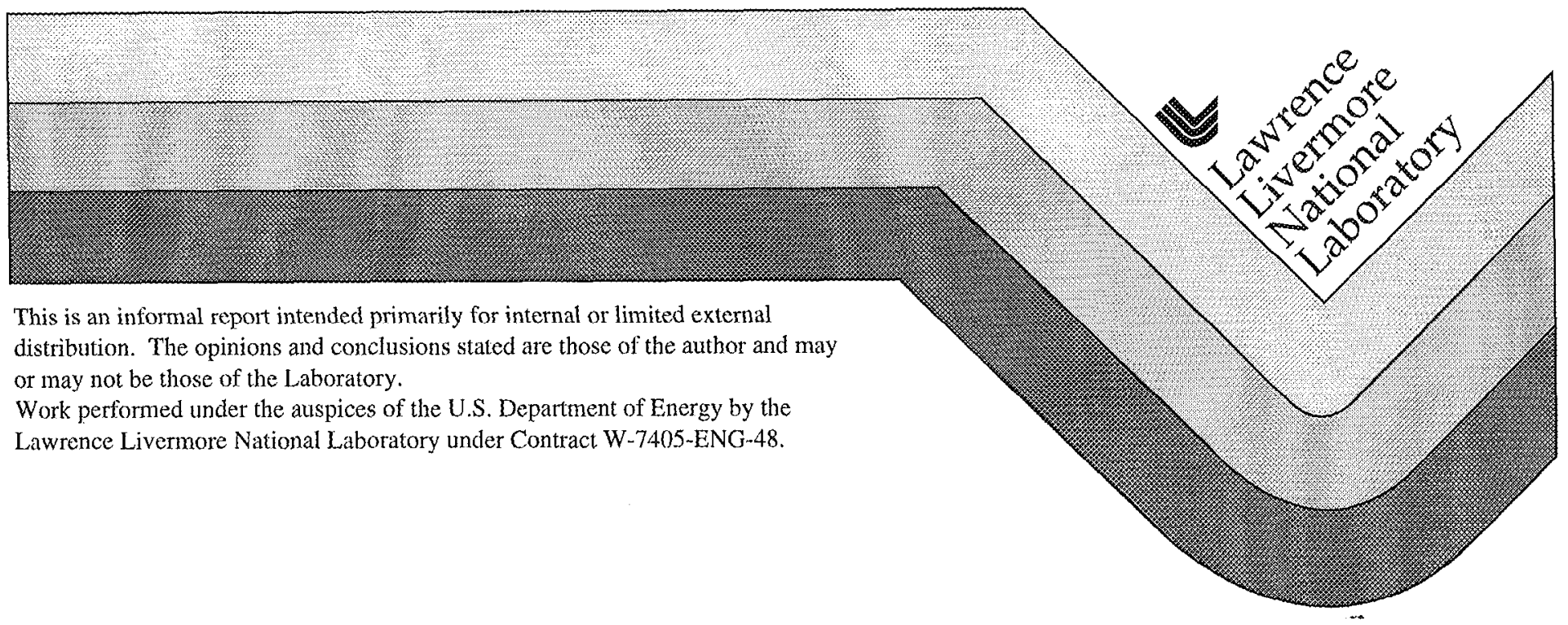




\section{DISCLAIMER}

This document was prepared as an account of work sponsored by an agency of the United States Government. Neither the United States Government nor the University of California nor any of their employees, makes any warranty, express or implied, or assumes any legal liability or responsibility for the accuracy, completeness, or usefulness of any information, apparatus, product, or process disclosed, or represents that its use would not infringe privately owned rights. Reference herein to any specific commercial product, process, or service by trade name, trademark, manufacturer, or otherwise, does not necessarily constitute or imply its endorsement, recommendation, or favoring by the United States Government or the University of California. The views and opinions of authors expressed herein do not necessarily state or reflect those of the United States Government or the University of California, and shall not be used for advertising or product endorsement purposes.

This report has been reproduced directly from the best available copy.

Available to DOE and DOE contractors from the Office of Scientific and Technical Information P.O. Box 62, Oak Ridge, TN 37831

Prices available from (423) $576-8401$

Available to the public from the National Technical Information Service

U.S. Department of Commerce 5285 Port Royal Rd. Springfield, VA 22161 
University of California

IIL Lawrence Livermore

National Laboratory

YUCCA MOUNTAIN PROJECT

Technical Implementing Procedure

Subject:

Receiving, Handling, and Storage of Specimens for LongTerm Corrosion Testing
No.:

Revision:

Eflective Date:

Page:

AUTHOR:
TIP.CM-02

0

1 of 4

Training Required: Yes No

Comments:

Training required for personnel performing work to this TIP.

REVISION HISTORY

Rev. No, CNNo, Effective Date Descristion ef Revisien/CN.

0

$10 / 11 / 95$

Initial issue

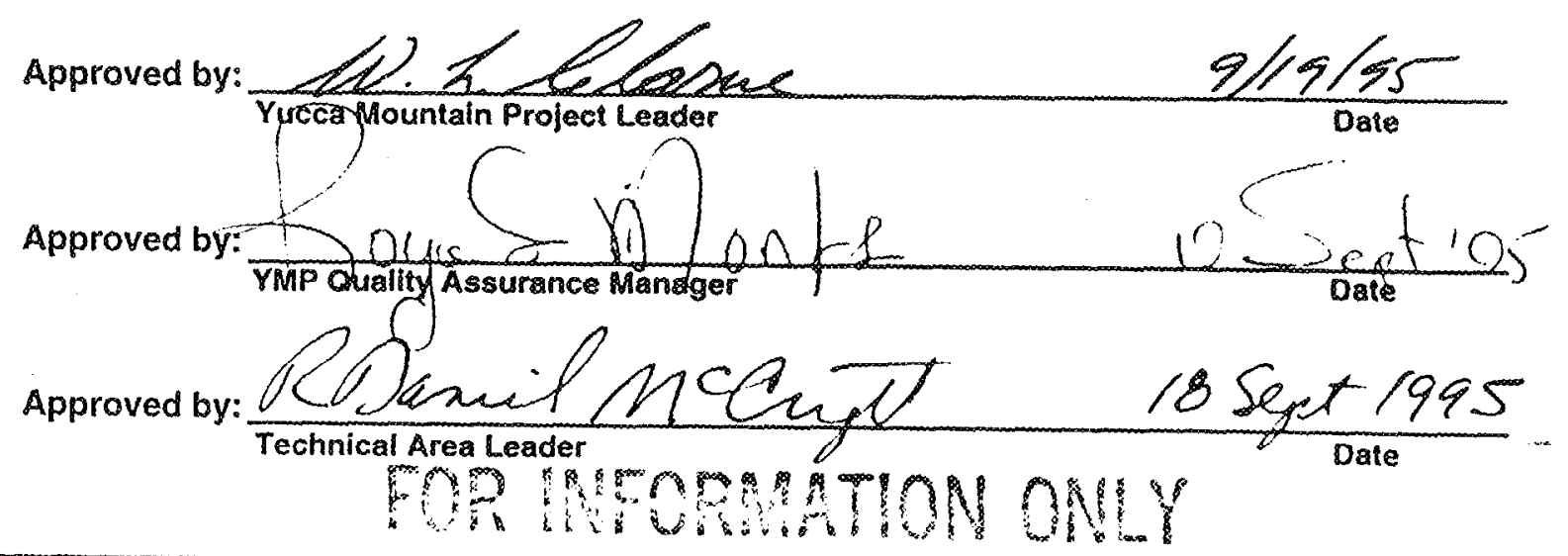




\begin{tabular}{|l|l|l|l|l|}
\hline No: & Revision: & Page: & \\
2 & $10 / 11 / 95$ & of 4 \\
\hline
\end{tabular}

\subsection{PURPOSE}

The purpose of this TIP is to describe the procedures that will be followed in order to ensure that the test specimens for Activity E-20-50, "Long-Term Corrosion Studies" are received, handled, and stored in a manner in which they are not damaged, degraded, or lost. This TIP was written to comply with LLNL YMP procedure 033-YMP-QP 13.0, "Handling, Storage, and Shipping."

\section{$2.0 \quad$ SCOPE}

This TIP covers receipt of the specimens at LLNL from the vendor, storage of the specimens before and after testing, and handling during post-test analysis.

The identification and control of the specimens during storage, testing, and analysis is covered by TIPCM-01, "Accounting of Test Specimens for Long-Term Corrosion Testing," which satisfies the requirements of LLNL YMP procedure 033-YMP-QP 8.0, "Identification and Control of Items, Samples, and Data."

At the completion of the activity, the specimens will be stored in their protective packaging for at least one year or until it has been decided by the TAL that storage is no longer warranted.

\section{$3.0 \quad$ RESPONSIBILITIES}

The Principal Investigator (PI) or designee is responsible for:

- the conduct of the activities and methods described in this procedure,

- maintaining scientific notebooks.

The Task Leader (TL) is responsible for:

- $\quad$ assuring that the requirements of this procedure are implemented.

The Technical Area Leader (TAL) is responsible for:

- verifying that this procedure meets the objectives of the applicable Scientific Investigation Plans and other project planning documents such as Activity Plans.

The YMP Quality Assurance Manager is responsible for:

- monitoring the implementation and for assuring the continuing effectiveness of the applicable controls.

\subsection{PROCEDURES}

4.1 Receipt of specimens at LLNL

- LLNL Shipping and Receiving will be instructed to notify the PI or designee upon receipt of shipping packages 


\begin{tabular}{|l|l|l|l|l|}
\hline No.: & Revision: & Page: & \\
& 0 & $10 / 11 / 95$ & 3 & of \\
\hline
\end{tabular}

- the PI or designee will assist in acceptance of the specimens and ensure that they are handled properly

- specimen identification numbers will be verified for agreement with procurement document specifications

- verify that materials specification documentation is received with specimens

-. specimens that do not meet the requirements of the purchase requisition will be identified and segregated in accordance with LLNL YMP procedure 033-YMP-QP 15.0, "Nonconforming Items"

- receipt of the specimens will be documented in the scientific notebook

\subsection{Specimen storage before testing}

- $\quad$ specimens will be stored in a locked cabinet (e.g.. Stanley-Vidmar type cabinẹt) in reasonable proximity to the testing area

- $\quad$ keys to the cabinets will be limited to LLNL YMP personnel involved with the activity

- at the Pl's discretion, specimens may remain in their protective shipping packages prior to preparation for testing or they may be repackaged in another protective package

4.3 Specimen storage after testing and in-between analysis

- $\quad$ specimens will be stored in a locked cabinet (e.g., Stanley-Vidmar type cabinet) in reasonable proximity to the testing area

- each specimen after removal from testing and in-between post-test analysis will be placed in its own inert protective packaging

- if the identification number has been obscured by corrosion product, a label with the specimen ID \# will be attached

- specimen will be stored so as not to be damaged or contaminated

4.4 Handling and storage during analysis

- Specimens will remain in their protective packaging whenever they are not being analyzed

- if analysis of a specimen requires that it be sectioned, the pieces of the specimen will be placed in labeled separate storage packages after analysis

- $\quad$ specimens will be returned to the storage cabinet immediately after completion of analysis

- specimens will be handled so as not to be unintentionally damaged or contaminated (e.g., gloves will be worn during handling)

\subsection{TRAINING}

Personnel responsible for handling of the specimens for Activity E-20-50 will be trained to this TIP. 


\subsection{APPLICABLE SPECIMENS}

This TIP applies to those specimens that were procured for Activity E-20-50, "Long-Term Corrosion Studies."

\subsection{SPECIMEN STORAGE}

The specimens will be stored in packaging that protects them from damage and contamination. The shipping packages from the vendor are adequate until the specimen are to be prepared for testing. After testing, plastic bags that protect the specimens from the atmosphere (primarily moisture) will be used.

When not in testing or analysis, the specimens will be stored in locked cabinets (e.g. Stanley-Vidmar type cabinets).

\subsection{QUALITY SURVEILLANCES}

Periodic surveillances to verify that the requirements of the TIP are being implemented shall be performed.

\subsection{QUALITY ASSURANCE RECORDS}

The following are retained as Lifetime Quality Assurance records:

- $\quad$ scientific notebooks

- materials specification documentation from vendor

\subsection{ASSOCIATED ACTIVITY AND TIPS}

This TIP is written in association with Activity E-20-50, "Long-Term Corrosion Studies." A companion TIP for identification and control of the specimens is TIP-CM-01, "Accounting of Test Specimens for Long-Term Corrosion Testing." 